\title{
Game of Property Rights and System Change*
}

\author{
Peng LIANG \\ Beijing Technology and Business University, Beijing, China
}

\begin{abstract}
Governments' protection and support are very important for rural enterprises during their birth and development. But, in fact, governments own the rights to control the operation of rural enterprises to a large extent. Governments encourage and lead the reform of property rights of rural enterprises. Why governments are willing to give up vested interests, and actively promote the reform of property rights of rural enterprises? This seems to be the key to explain the reform of property rights of rural enterprises. This paper puts forward the hypothesis, uses mathematical models and statistical analyses, and adopts relevant data to verify the needs of governments for fiscal targets, and the rationality of their behavior actively encourages and promotes reconstruction during the reform for maximizing their interests.
\end{abstract}

Keywords: property rights, game theory, system change

\section{Introduction}

One miracle in China's rural reform is the emergence of rural enterprises, with obvious achievements. It has broken the framework of single agricultural economy in the rural areas, and has promoted the change from the single planned economy to market economy in China, accounting for half of the national economy. However, since the 1990s, rural enterprises have suffered challenges of the buyer's market in the market economy, technological innovation, macroeconomic technical adjustments, and their own inherent weaknesses, with the pace of development slowed down, and have shown the defects in the property rights system of rural enterprises, rural enterprises began the reform of property rights (Williams, 2001). According to the analysis, it is shown that the reform of property rights of rural enterprises has top-down-driven feature, rather than the past mainstream view of the bottom-up-driven feature. The analysis of "the most important reason for the reform of enterprise property rights” shows that, the most important driving force for reform of enterprise property rights is the consideration and activeness of governments at county level and above, rural governments, and enterprise operators. Almost $100 \%$ of the enterprise reconstructions are led by these three interests-related parties (Du, Yuan, \& Bao, 2004). It can be found that governments have played a positive role in promoting and facilitating the reform of property rights of rural enterprises.

Rural enterprises are established by local rural governments. The purpose at the beginning of the establishment is to increase the income of community residents and the financial revenue of community governments, and provide community employment opportunities (Che \& Qian, 1998). In the process of the

\footnotetext{
* The research is funded by the Youth Scientific Research Funds of Beijing Technology and Business University (No: QNJJ2011-14).

Peng LIANG, Ph.D., Lecturer of School of Economics, Beijing Technology and Business University.

Correspondence concerning this article should be addressed to Peng LIANG, School of Economics, Beijing Technology and Business University, Haidian District, Beijing, 100048, China. E-mail: liangzi2611@hotmail.com.
} 
development of rural enterprises, governments have the close relationship with rural enterprises. Governments' protection and support are very important for rural enterprises in their early development. However, on the other hand, enterprises have to pay a price for taking governments to act as managers. Governments may sacrifice the efficiency of enterprises for their own goals, such as their own income and capital gains. Meanwhile, rural enterprises have also undertaken various local obligations and social spending. For governments, owning the right to control rural enterprises not only can make them accessible to a variety of economic benefits, but also is conducive to achieve multiple objectives to improve their own achievements. Governments would make not only economic requirements, but also requirements beyond the economy of rural enterprises. Therefore, what is the reason that governments are willing to give up the control of rural enterprises, to give up their own vested interests, but to actively promote this reform of property rights of rural enterprises? This paper will put forward its own framework for theoretical analysis and use mathematical models and statistical analyses to prove the rationality of governments' restructuring behavior in the process of reconstruction.

\section{Analysis of Government's Fiscal Pressures and External Profits}

With the changes of market environment since 1990s, rural enterprises would likely be a great burden for the government due to the soft budget constraints similar to state-owned enterprises in case of rural enterprises' slowed growth rate, decreased ability to absorb surplus labor as well as a proper certain enterprises involved in debt with heavy losses, then the government wishes to cut its debt chain with rural enterprises as soon as possible so as to avoid the tendency of rural business risk (especially for the rural enterprises with poor operation), how to cut the relationship with rural government on its own initiative becomes the greatest concern of the government (William \& Li, 1990).

Data suggest that the interest burden rate of rural enterprises rises from 45.58 in 1995 to 48.07 in $1998(\mathrm{Li}$, $\mathrm{Du}, \&$ Wang, 2004). Because of getting a guarantee from the government, rural enterprises can only obtain loans from the financial institutions such as a bank, credit union, etc.. Some others will be obtained through other non-regular channels in case rural enterprises are difficult to obtain loans from bank or credit union, in the late of 1980s, many enterprises are operated on borrowings by calling for funds from society, however, the guarantee is just the government ( $\mathrm{Li}, 1998)$. Obviously, therefore, in case of slowing development and decreased performance of rural enterprises, the government will face the risk to bear contingent debt shift from the debt that rural enterprises are unable to repay. The government's judgment of this predictable risk will also directly impact its attitude toward reformation. In case rural enterprises are under poor operation, the prediction of the government to bear the debt risk is increased, the government hopes to cut its debt chains with rural enterprises as soon as possible so as to avoid the increased tendency of rural enterprises' operation risks. Therefore the government certainly will play an active role in the process of rural enterprise reformation.

\section{Government's Revenue Opinion}

The greatest essential feature of rural enterprises' property rights is that the actual rights of enterprises are controlled by both managerial staff of enterprises and the government where the enterprises located (Russell Smyth Rural, 1999). However, with the degree of marketing greatly increased, the new form of market competition challenges the former structure of property rights, the value of various economic and organizational resources owned by the government is depressed, meanwhile the disadvantages caused by 
sacrificing production efficiency for achieving multiple target of rural enterprises are exposed with decreased production performance of enterprise as well as generally declined economic benefits (Peng, 1996). As previously analyzed, the government also has the motivation to completely get rid of bearing the contingent debt risk due to being guarantee in the process of rural enterprises borrowing loans and raising funds. So, the government will also actively promote rural enterprises reformation even if for its own interests. The behavior of the government in the reform indicates that it also seeks for the maximized interests. On the other hand, the government's stable profits cannot be either guaranteed in case the performance of rural enterprises is declined or even worse, but the government becomes more concerned about enterprises' production performance due to the tax reform in 1994. The performance of rural enterprises is not only involved in the government's profits obtained from the enterprises, but also the tax base of tax submitted by the enterprises, which finally may influence the fiscal revenue of the government. Therefore improving the performance of rural enterprises seems to be the key point of government to maximize its profits. The ambiguous property rights of rural enterprises cannot efficiently encourage the business operators, in order to improve the operation performance of enterprises, the government has the strong motivation to promote rural enterprises' reformation so as to ensure maximization of the vested interest. Moreover, the reformation has become an important indicator, thus a wide range of reformation of rural enterprises is appeared. All in all, on the one hand, the reformation of rural enterprises is related to how the enterprises select an effective technical route so as to improve the market competition condition, on the other hand, related to how government balances tax profit income to the pursuit of maximization of the interests.

\section{Hypothesis}

One of the purposes of rural enterprises is to increase governments' revenue (Weitaman \& Xu, 1994). We can divide the disposable income of government from the rural enterprises into three parts: tax revenue, profits revenue, and agricultural building revenue. The tax revenue is the sum of tax revenue turned over by the enterprise, including national tax and local tax. It is the redistribution of enterprise's income and closely related to production performance which means the better the production performance, the more tax it will turn over. Profit revenue is the profit-sharing of the town according to the shares of the town holds in the rural enterprise. The higher proportion of the collective capital in the total capital, the more profits need to be turned over to the government. From the definition of the rural enterprises, we can easily see, one of the purposes of creating rural enterprises is to bear the obligation to support agriculture. In addition, the law of China's rural enterprises defines that the rural enterprises should bear this kind of obligation. It has a great relationship with the property rights of the rural enterprises. Since the government can allocate the agriculture building supporting revenues freely like the profit income, so in this article, the both parts are divided into the same class and referred to as profit revenues turned over by the enterprise collectively.

According to the hypothesis, if the government promotes restructuring of the rural enterprises actively, the results are as follows: On the one hand, after the restructuring of rural enterprises, the proportion of collective capital in total capital will be reduced, the profit revenues of the government will be less and the total revenues

will be less accordingly. On the other hand, the performance of the enterprises will be improved because the new incentives increase the efficiency. From the preceding analysis, it can be seen that the government can obtain more tax revenues because of the improvement of the enterprise performance, and the total revenues will be improved accordingly. The government can invest the sunk capital which is replaced during the restructuring 
of the rural enterprises into better projects, to activate the collective capital. The short tenure of the government officers determines the short-term nature of their behavioral decisions. It is likely that the government will blindly pursue the maximization of fiscal revenues and the highlights of short-term achievements.

It can be seen from this hypothesis that the restructuring of rural enterprises will impact the revenues of the government. Before the restructuring, the total revenues of the government cannot be guaranteed because the declining of the performance of the enterprises, and the government has a poor expectation on the institutional arrangements of rural enterprises. After the restructuring, the government has a stronger confidence on the improvement of tax revenues, and then it will actively promote the restructuring of rural enterprises. The motive of the government to promote the restructuring of the rural enterprises can be found through investigation of whether there are significant differences and changes between the tax revenues and the profit revenues of the government. In order to investigate the tendency and preference of the government between the tax revenues and the profit revenues, here are the analyses and arguments.

\section{Argument 1: Data Validation}

We use data on a sample survey of 100 enterprises in Jiangsu Province to prove the hypothesis. Seeing from the data of the restructuring process, with the change in ownership structure, the total revenue of the enterprises has been increased which means the performance of the rural enterprises has been improved with the restructuring. The disposable revenues that the government obtained from the rural enterprises have been increased of which the tax revenues have been increased and the profit revenues have been declined. Through the comparison of total revenues of the government in 1995 and 2000, we can find that the disposable revenues of the government have been increased significantly. The major reason is that the tax revenues have been increased greatly, because the profit revenues of this period have been declined. However, it is likely that the increase of tax revenues and the decline of profit revenues are caused by the improvement of tax rate and the decline of capital gain rate. After the reform of the tax system, the tax rate changing little and the upward trend of the enterprise capital gain rate shows that, as previously analyzed, the increase in tax revenue due to the increase of the tax base and the decline of profit revenues is because of the decline of the capital and the changes in the ownership structure (see Table 1).

Table 1

Government's Revenues From the 100 Sampling Rural Enterprises in 1995-2000 (Unit: Ten Thousand Yuan \%)

\begin{tabular}{lcccccccc}
\hline Year & 1995 & 1996 & 1997 & 1998 & 1999 & 2000 & Overall trend \\
\hline Disposable revenues & obtained & $3,550.4$ & $4,294.6$ & $5,047.9$ & $5,627.7$ & $6,776.4$ & $7,515.7$ & Raising \\
by the government & 3,418 & $4,137.6$ & $4,866.5$ & $5,435.6$ & 6,598 & 7,422 & Raising \\
Tax revenue & 132.4 & 157 & 181.4 & 192.1 & 178.4 & 93.7 & Falling \\
Profit revenue & 138,000 & 150,778 & 163,773 & 153,816 & 167,105 & 204,048 & Raising \\
Total revenue & 4.75 & 5.30 & 5.45 & 5.65 & 5.77 & 5.82 & Raising \\
Capital gain rate & & & & & &
\end{tabular}

Note. Source: A part is from Professor Du, 2006 and the financial indicators' changes of the 100 enterprises, the rest is calculated from the data.

It can be seen from the data change in the figure that in the condition of tax revenue and profit income having different variation tendency, the government may adopt effective ways to promote rural enterprises' reformation so as to pursue the maximization of benefits. Because this collected data may cover the varying differences among sample data, this article will adopt the functional model and statistical model to further 
discuss and analyze the rationality of government behaviors.

\section{Method 1: Functional Model}

The government realizes the maximization of total income items' benefits through balancing tax revenue and profit income of income items.

If total government income: $z$; tax revenue: $x$; profit income: $y$; proportion of tax revenue: $p 1=x / z$; function with proportion of time $f(t)=p 1(t)$, called tax ratio function; proportion of profit income: $p 2=y / z$; function with proportion of time $u(t)=p 2(t)$, called profit ratio function.

Table 2

Tendency of the Proportion of Tax Revenue

\begin{tabular}{lllllll}
\hline$i$ & 1 & 2 & 3 & 4 & 5 & 6 \\
\hline$t$ & 1995 & 1996 & 1997 & 1998 & 1999 & 2000 \\
$f(t)$ & 0.9627 & 0.9634 & 0.9641 & 0.9659 & 0.9736 & 0.9875 \\
$\quad \Delta_{f}(t)$ & & & & & & \\
Annual changing rate of proportion & & -0.0053 & 0.0007 & 0.0018 & 0.0077 & 0.0139 \\
\hline
\end{tabular}

Since 1996, the proportion significantly increased year by year, and the changing rate of proportion also increased year by year.

Table 3

Tendency of the Proportion of Profit Income

\begin{tabular}{lllllll}
\hline$i$ & 1 & 2 & 3 & 4 & 5 & 6 \\
\hline$t$ & 1995 & 1996 & 1997 & 1998 & 1999 & 2000 \\
$u(t)$ & 0.0373 & 0.0366 & 0.0359 & 0.0341 & 0.0264 & 0.0125 \\
$\Delta_{u}(t)$ & & 0.0053 & -0.0007 & -0.0018 & -0.0077 & -0.0139 \\
Annual changing rate of proportion & & & & & & \\
\hline
\end{tabular}

Since 1996, the proportion significantly reduced year by year, and the changing rate of proportion also reduced year by year.

\section{Result Analysis}

(1) It can be seen from the calculated results in Table 2 that the government's dependence on tax revenue is strengthening. Compared the evaluation figure from 1995 to 2000, the proportion of tax revenue is increasing year by year from 0.9672 in 1995 to 0.9875 in 2000. In addition, the proportion is also increasing gradually.

(2) It can be seen from the calculated results in Table 3 that compared with tax revenue, profit income is reducing gradually in the government income from 0.0327 in 1955 to 0.0125 in 2000. In addition, the proportion is also reducing year by year. The enlarging gap between tax revenue and profit income is obvious. Furthermore, the longer of the time span, the larger of the gap. Combining the tendency of increasing tax revenue and increasing reduction of profit income in Table 1, we can completely conclude that the government can acquire the maximization of self-benefits through the rural enterprises' reformation.

We can see from the model that the proportion of taxes and the changing rate of proportion are increasing year by year, and the proportion of profit and the changing rate of proportion are reducing year by year. The government strengthens their confidence of increasing tax revenue through reformation, and the total income of government has the tendency of increasing year by year. This shows that through balancing the different variation tendency of tax revenue and profit income, the government is willing to promote the reform of 
property rights of rural enterprises positively so as to realize the maximization of self-benefits.

\section{Method 2: Verification by Statistical Model}

In order to further verify the reliability of difference in data, statistical analysis is used to verify the hypothesis. Methods in details are as follows.

In order to verify the reasonable hypothesis about governments' behaviors, we will do the correlation analyses of tax proportion and profit proportion through statistical analysis.

The following is the analysis of the two statistics:

$$
r_{\text {tax }, y z}=\frac{S_{y z}}{S_{y} S_{z}}
$$

Equation (1) demonstrates the correlation between the tax proportion and years.

$$
r_{\text {profit }, v z}=\frac{S_{v z}}{S_{v} S_{z}}
$$

Equation (2) demonstrates the correlation between the profit proportion and years.

Table 4

Result of Tax Proportion and Profit Proportion

\begin{tabular}{lllllll}
\hline$i$ & 1 & 2 & 3 & 4 & 5 & 6 \\
\hline Tax proportion $y$ & 0.9627 & 0.9634 & 0.9641 & 0.9659 & 0.9736 & 0.9875 \\
Years $z$ & 1995 & 1996 & 1997 & 1998 & 1999 & 2000 \\
Profit proportion $v$ & 0.0373 & 0.0366 & 0.0359 & 0.0341 & 0.0264 & 0.0125 \\
\hline
\end{tabular}

Covariance:

$$
\begin{aligned}
& S_{y z}=\frac{1}{n-1} \sum_{i=1}^{n}\left(Y_{i}-\bar{Y}\right)\left(Z_{i}-\bar{Z}\right)=0.0782 \\
& S_{v z}=\frac{1}{n-1} \sum_{i=1}^{n}\left(V_{i}-\bar{V}\right)\left(Z_{i}-\bar{Z}\right)=-0.0782
\end{aligned}
$$

Tax proportion:

$$
S_{y}=\sqrt{\frac{1}{n-1} \sum_{i=1}^{n}\left(Y_{i}-\bar{Y}\right)^{2}}
$$

Variance $=0.0216$

Years:

$$
S_{Z}=\sqrt{\frac{1}{n-1} \sum_{i=1}^{n}\left(Z_{i}-\bar{Z}\right)^{2}}
$$

Profit proportion:

$$
S_{v}=\sqrt{\frac{1}{n-1} \sum_{i=1}^{n}\left(V_{i}-\bar{V}\right)^{2}}
$$

Finally, obtained:

$$
\text { Variance }=0.0216
$$

$$
r_{t a x, y z}=\frac{S_{y z}}{S_{y} S_{z}}=0.8654
$$




$$
r_{\text {profit }, v z}=\frac{S_{v z}}{S_{v} S_{z}}=-0.8654
$$

\section{Result Analysis}

According to the statistical analysis theory, the relevant amount $r$ value is between $[-1,1]$. If the closer to 1 of the result required, the higher of positive correlation; the closer to 0 , the worse of correlation; the closer to -1 , the higher of negative correlation; and the closer to 0 , the worse of correlation. According to the $r$ value above, we can see that the correlation $r$ value of tax proportion and years is 0.8654 , the result is close to 1 , and the correlation is positive correlation and high correlation. This demonstrates that with the years increasing year by year, tax revenue proportion in government's total income shows the increasing tendency gradually, therefore this also demonstrates that government's dependence on tax revenue is strengthening. It is seen from the correlation $r$ value of profit proportion and years that the calculated result is -0.8654 , close to -1 , which demonstrates the correlation is negative correlation and high correlation. This also illustrates that with the increasing of tax proportion gradually, the proportion of profit income in government's income shows the reducing tendency year by year. The obvious difference variation does exist between profit income and tax revenue for the government, therefore government's confidence by increasing tax revenue through reformation is strengthening, and it prefers tax revenue more. Therefore the government will promote rural enterprises' reformation positivity. This is exactly the same as the hypothesis mentioned before.

\section{Conclusions}

Thorough verification of hypothesis of methods of mathematics and statistical analysis, we can see clearly that in the process of rural enterprises' reformation, government's role and behaviors of positively promotion accord with the aim of pursuing the maximization of benefits. In the new competitive market environment, government impelled by the new tax system becomes more sensitive of market performances. The previous analysis in this article shows that the rural enterprises' former structure of property rights cannot provide an effective incentive mechanism to improve the performance of the enterprises, so it is not helpful for the government to acquire the profits of capital—profit income. However, the reformation can ameliorate the performance to add tax base, so as to further improve the tax revenue. When finding that the reformation can add tax revenue to make up the reduced profit income to enhance total self-profits, the government will promote this reformation positively and become a powerful driving force of this reformation.

\section{References}

Che, J. H., \& Qian, Y. G. (1998). Institutional environment, community government, and corporate governance: Understanding China's rural-village enterprises. Journal of Economics and Organization, 14, 1-23.

Du, Z. X., \& Yoichi, I. (2006). Does property right transformation improve rural and village enterprises performance? Journal of China and World Economy, 14, 85-101.

Du, Z. X., Yuan, P., \& Bao, Z. S. (2004). Study on the property rights, ownership structure and employee's participation. Journal of Management World, 1, 82-156.

He, L. Q., \& Du, H. (1992). Rural industrial enterprises and the role of local governments: A Chinese case study. In D. Jones, \& J. Svejnar (Eds.), Advances in the economic analysis of participatory and labor managed firms: A research annual. JAL, Greenwich CT. 
Li, K. Y., Du, M., \& Wang, L. H. (2004). Change and comprehension of property institution in rural enterprises. Journal of Agriculture Research, 1, 90-93.

Li, P. P. (1998). The puzzle of China's rural-village enterprise: The paradox of local corporatism in a dual-track economic transition. Journal of Management and Organization Review, 1, 197-224.

Peng, X. L. (1996). Rural-village enterprises, local government and rural communities: The Chinese village as a firm during economic transition. Journal of Economic of Transition, 4, 43-46.

Russell, S. L. (1999). Rural enterprises in Jiangsu Province, China: Recent institutional changes and future prospects. Journal of Development Policy Review, 17, 191-213.

Weitaman, M. L., \& Xu, C. (1994). Chinese rural-village enterprises as vaguely defined cooperatives. Journal of Comparative Economic, 18, 121-145.

William, B., \& Li, Q. S. (1990). China's rural industry: Structure, development and reform. New York: Oxford University.

Williams, H. (2001). Property rights and legal reform in rural and village enterprises in China. Journal of Asian-Pacific Law and Policy, 2, 227-258. 